D) Check for updates

Cite this as: $B M J 2020 ; 370: m 3746$ http://dx.doi.org/10.1136/bmj.m3746

Published: 30 September 2020

\section{Safely returning clinically vulnerable people to work}

In this editorial by Ewan Macdonald and colleagues (BMJ 2020;370:m360o, 21 September 2020, doi:) we inadvertently added an extra o to the number of UK jobs lost. The correct number is $700 \mathrm{ooo}$. The online version has been corrected. 